\title{
Redefinition of Homecoming (Mudik) VS Returning Home (Pulang Kampung) in the Context of Covid-19 Pandemic
}

\author{
Riani
}

\author{
Balai Bahasa Provinsi DIY, Yogyakarta, Indonesia \\ Email: riani.balaiyogya@gmail.com
}

\begin{abstract}
Heading Eid al-Fitr, Muslims in Indonesia usually do homecoming (mudik) to their hometowns. However, recently in the pandemic Covid-19 era, the term homecoming has been redefined by Jokowi. He distinguished the meaning of homecoming (mudik) with returning home (pulang kampung). However, based on the Indonesian Dictionary, the term homecoming is equated with or defined as returning home. This study aims to investigate language experts and another experts' redefinition of mudik. The appraisal theory was employed to reveal the expert's attitude, engagement, and graduation toward the issue. Data for this study were obtained from online news media containing language expert's opinion on the word homecoming (mudik) and returning home (pulang kampung) reported on Detik online news titled 'Perbedaan Mudik dan Pulang Kampung Menurut Para Ahli' and Republika online news titled 'Pakar Linguistik Jelaskan Soal Arti Mudik dan Pulang Kampung'. The results of the study indicate that the experts have a positive attitude, engagement, and gradation to support the government to redefine mudik for handling the spreading of COVID -19 in Indonesia.
\end{abstract}

Keywords: Homecoming, returning home, appraisal theory

\section{INTRODUCTION}

Indonesia government socializes physical restriction appeal in preventing the spread of Covid-19. The appeal means that everyone keeps a distance from other people (at least 1 meter) or everyone is prohibited from gathering because there is a concern that the virus will be easily transmitted through droplet or air transmission. This regulation is further tightened before the Eid alFitr holiday around May 2020. One of the traditions of the Indonesian people ahead of Eid is to return to their hometowns to gather with family or mudik (homecoming). The movement of large numbers of people back to their hometowns is inevitable. They will use a mode of transportation that has the potential to create crowds so that the spread of the virus will become even more massive both in their cities and hometowns. Therefore, the government socializes appeals to staying at home or not homecoming (mudik) (Prabowo, 2020).

President Jokowi also conveyed an appeal for not going home to hometown when interviewed by Najwa Shihab in the Matanajwa talk show with the theme
Jokowi Diuji Pandemi on Wednesday, the $22^{\text {nd }}$ of April, 2020. Initially, Najwa Shihab said that nearly 1 million people had gone home and were scattered in various regions. Responded to this fact, Jokowi said, "That is not homecoming (mudik). That's called going home. Indeed they work in Jabodetabek, there they no longer have jobs, so they go home because their wife and child are in the village." The interview raised controversy in the community or among linguists or other experts because the words homecoming and returning home previously had no different meanings. According to Kamus Besar Bahasa Indonesia (2020), the word homecoming has the same meaning as going home.

The controversy was captured in the news headline. The reporters from Detik and Republika, the wellknown national online news portal, quickly launched a report on opinions of experts regarding the redefinition. The experts' opinion regarding the redefinition of the word homecoming among others reported on the Detik news portal with the title "Perbedaan Mudik dan Pulang Kampung Menurut Para Ahli" (Yunita, 2020) and news portal Republika with the news title "Pakar Linguistik 
Jelaskan Soal Arti Mudik dan Pulang Kampung" (Firmansyah, 2020).

The experts and reporters' opinions are interesting to study to find out whether they support or not the redefinition. Therefore, the study is aimed at describing the experts and reporters' attitude toward the redefinition by examining their attitude inscribed in the language. Martin and Rose (2003) define appraisal as an interpersonal meaning system that refers to the evaluation of attitude in a text, how a person expresses how strong his feelings are for something and the values for something in the text are generated. In this study, the appraisal theory plays an important role as an analysis tool to examine experts' and reporters' attitudes, gradation, and engagement, as inscribed in language.

\section{LITERATURE REVIEW}

Critical discourse analysis according to Foulchard (1993) is a discourse analysis that aims to explore systematically the relationship between causality and determination among discursive practices, events, and texts (as cited in Munfarida, 2014). Critical Discourse Analysis (CDA) and Systemic Functional Linguistics (SFL) have a relationship because their focus is a linguistic investigation. Both CDA and SFL view language as a social construction as language plays a role in society. Therefore, language can influence the context and vice versa. Both CDA and SFL highlight the semantic aspect viewed from the cultural aspect and the historical aspect (Young \& Harrison, 2004). Furthermore, SFL is both theory and tool to describe how the relationship between language and society, language and power, language, and social change. Through discourse analysis in a real language context, SFL unravels the relation between power and ideology in detail and transparently. General social functions of SFL are interpersonal, ideational, and textual (Young \& Harrison, 2004).

The appraisal is part of interpersonal functions and is used to explore the negotiating attitude inscribed in the language (Martin \& Rose, 2007). Appraisal has three domains, namely attitude, engagement, and graduation (Martin \& White, 2005). Attitude is related to feelings and includes feeling reactions to someone or an event, judgments about someone's behavior, and judgments about objects. Meanwhile, engagement is related to the source of the assessment, and graduation is related to the hard or soft words of the assessment. It can be said that appraisal theory can be used to determine the attitude and feelings of a person or the media towards something. Therefore, this study uses appraisal theory to find out the attitudes of the experts, reported in media online Detik and Republika, towards redefining the word homecoming which is distinguished from returning home. This study is expected to enrich the realm of critical discourse analysis based on the SFL approach, especially Appraisal. Besides, this study is expected to improve the literacy or critical thinking skills of readers regarding the use of word or definition.

Researches applied appraisal theory on the object of research on printed or online news discourse have been carried out by many researchers, such as Ellyawati (2011), Winarni (2012), Nur and Hadi (2016), Pusparini et al. (2017), Gunawan et al. (2019), Daniarsa and Mulatsih (2020), and Burhanudin (2020). Ellyawati (2011) studies the news on the online news portals Detik.com and Kompas.com regarding the special treatment of Arthalyta Suryani, a convicted corruption, at the Pondok Bambu detention center. Winarni (2012) examines the discourse "Sungguh-Sungguh Terjadi" on the printed newspaper Kedaulatan Rakyat. Nur and Hadi (2016) study the comments on the Instagram comment column of the lipstick product account@kailijumei. Pusparini et al. (2017) focus on the news about the persecution of Duo Bali Nine in the mass media The Sydney Morning Herald, The Guardian Australia, The Jakarta Globe, and The Jakarta Post websites. Gunawan et al. (2019) review the news of the 211 reunion movement on the online media Tirto.id. Burhanudin (2020) examine the Kompas daily Instagram comment column on Ahok's position as the chief commissioner of State-Owned Enterprises. Daniarsa and Mulatsih (2020) reviewed the news in the Tempo mass media, entitled "Misunderstanding Papua" and in Kompas entitled "Exodus and Urgent Action."

These studies have applied the appraisal theory to determine the attitudes of language users. These studies also reflect how the flexible use of appraisal theory can dissect how language can show the tendency of language users' attitudes to problems. From the literature review, the study of redefining the word homecoming based on the opinion of linguists on the news portals Detik and Republika has not been carried out. Therefore, this study is to enrich the study of critical discourse analysis by using the appraisal theory approach.

\section{METHODS}

This research is a qualitative descriptive. The study used a qualitative method to describe data, characteristics, and relationships of phenomena systematically, factually, and accurately within a limited period according to Sugiyono (2011). The phenomenon studied in this study is the redefinition of the word homecoming that was conveyed by the government (Joko Widodo) just before Eid al-Fitr regarding the Covid-19 pandemic.

The data of this study were linguistic units in the form of words, phrases, and sentences found on the Detik.com portal entitled "Perbedaan Mudik dan Pulang Kampung Menurut Para Ahli" (Yunita, 2020) 
and the news on portal Republika.com with the title "Pakar Linguistik Jelaskan Soal Arti Mudik dan Pulang Kampung" (Firmansyah, 2020). The lingual unit data in both news items were analyzed using the Appraisal theory. Data is presented along with the analysis process in a way described and explained in words or formally.

\section{FINDINGS AND DISCUSSION}

The linguistic units of news text from Detik.com and Republika.com are analyzed and categorized by using appraisal theory.

\subsection{Attitude}

Martin and White (2005) divided attitude into effect, judgment, and appreciation. Affect relates to an emotional response to something, other people, yourself, or events that can be positive or negative. Judgment is an attitude or judgment, both positive and negative, on human behavior. Judgment is divided into the judgment of esteem and judgment of sanction. Meanwhile, appreciation refers to an assessment of natural phenomena. The judgment of esteem relates to normality: how normal a person is; capacity: how capable a person is; and tenacity: how persistent or tenacious a person is. Meanwhile, judgment sanctions are related to veracity: how honest or trustworthy a person is; and propriety: how ethical a person's behavior is. Appreciation refers to the evaluation of natural phenomena. In short, the appreciation is related to assessments that are aesthetic in nature (Martin \& White, 2005). These three aspects are used in investigating the experts' attitudes posted in the news on detik.com and republika.com.

Based on the analysis, it is found out that some data contain positive affect and negative affect, for example,

1. "Pertama, saya gembira karena akhirnya Presiden menyatakan dengan tegas: Dilarang Mudik." (+affect)

'First, I am happy that the President has finally stated firmly: Homecoming is prohibited'. (Effendi Gazali” (EG), Detik)

2. "Salah seorang wartawan senior yang juga aktif di Gugus Tugas kesal pada saya." (-affect)

'One of the senior journalists who was also active in the Task Force was upset with me.' (EG, Detik)

As shown in data 1, there is the word gembira "happy" that shows EG's feelings in the president's decision to prohibit going home. The word choice gembira "happy" shows a positive effect. Data 2 are taken from EG's statement explaining that there was a journalist who was disappointed because of the president's hesitant attitude to prohibit homecoming.
Related to the capacity of Joko Widodo, some data contain negative and positive judgment as follows.

3. "Presiden tidak boleh mencla-mencle". (judgement)

'The president must not be hesitant'. (EG, Detik)

4. Pertama, saya gembira karena akhirnya Presiden menyatakan dengan tegas: Dilarang Mudik.

'First, I am happy that the President has finally stated firmly: homecoming is forbidden'. (EG, Detik)

As show in data 3 , there is the adjective mancla mencle 'hesitant' as negative judgment giving by EG toward the president. EG considers that the president is hesitant to prohibit homecoming. The president's attitude is considered not showing a good leader's attitude. In data 4, there is adverbial phrase dengan tegas 'firmly' as a positive judgment on Jokowi's capacity as a president.

Meanwhile, the positive appreciation is found out in data 5 as follows.

5. "Apalagi beliau memiliki pengaruh yang sangat besar sebagai orang nomor satu di Republik ini”. (+ appraisal)

'Moreover, he has enormous influence as the number one person in the Republic'. (Mahsun (M), Republika)

M expresses his positive appreciation to the president by calling him nomor satu 'number one'. M's statement implies that $M$ supports the presidential decision because the president has a huge influence that redefining the word homecoming is acceptable.

On the other side, reporters of Detik and Republika give positive tenancy judgment to the experts that they are interviewed.

6. "Perbedaan Mudik dan Pulang Kampung Menurut Para Ahli” (+ Judgement)

'The Difference between Homecoming and Going Home According to Experts' (Reporter, Detik)

7. "Prof. Effendi Gazali, MPS ID., Ph.D, Peneliti Komunikasi yang juga Pengajar dan Pembimbing Disertasi di Program Pascasarjana Universitas Indonesia”. (+ Judgement)

'Prof. Effendi Gazali, MPS ID., Ph.D., Communication Researcher who is also a Lecturer and Dissertation Advisor at the University of Indonesia Postgraduate Program'. (Reporter, Detik) 
8. "Guru Besar Bidang Linguistik Universitas Mataram Prof Mahsun berpendapat kata "mudik" dan "pulang kampung" memiliki makna yang sama." (+ Judgement)

'Professor of Linguistics at the University of Mataram Prof. Mahsun argued that the words "homecoming" and "returning home" have the same meaning'. (Reporter, Republika)

As shown in data 6, which is the headline, there is a noun phrase para ahli 'experts'. This phrase shows the capacity or ability of the interviewees as credible experts in their field. On data 7 and data 8 the reporter writes down the titles and professions of the experts. The mention of degree and profession aims to provide an assessment that they are experts in their field and deserve to be heard and trusted.

\subsection{Gradation}

Martin and White (2005) stated that graduation refers to a shift in meaning expressed by the reader or listener that is marked by the use of particular emphasis on a phrase. For example, the word 'very' before the adjective 'hard' has given a grade of the texture of something. Some data contain gradation are as follows.

9. "Tapi mereka memang pergi ke udik (hulu sungai)” (+ Gradation)

'But, they indeed go to udik (upstream)' (DR, Detik)

10. “...barangkali Presiden kita punya cukup data bahwa...". (+ Gradation)

'...perhaps our President has sufficient data that...' (EG, Detik)

As shown in data 9, intensifier word memang 'indeed' is used to emphasize the verb to go to udik or homeland. In data 10 there is an intensifier barangkali 'perhaps' as the expert's positive opinion who assumes there is a slight possibility that the President already has data on the number of going home.

\subsection{Engagement}

Martin and White (2005) state that engagement is "directed towards identifying the particular dialogic positioning associated with given meanings and towards describing what is at stake when one meaning rather than another is employed". Engagement functions to describe relations between the speaker/writer and the listener/reader. Engagement is divided into two, namely heterogloss and monogloss. Heterogloss refers to the source of an attitude other than the writer. Monogloss refers to the source of the attitude of a writer.
The Detik and Republika news portals contain heterogloss because they have two sources, namely experts and reporters.

The following data contain engagement on Detik.com and Republika.co.id.

11. "Menurut Devie, secara praktik mudik menjadi dekat dengan tradisi para migran...”. (+ Engagement)

'According to Devie, in practice homecoming is close to the tradition of migrants...' (DR, Detik)

12. "Menyitir temuan Maman Mahayana, dalam kamus ...”. (+ Engagement)

'Citing Maman Mahayana's findings, in dictionary...'. (DR, Detik)

As shown in data 11 and 12, there are projecting clauses characterized by the use of reference word menurut 'according to' and menyitir 'citing' which refers to experts' opinion. The reference word is used to strengthen the experts' opinion to convince the reader that their opinion is worth to trust.

The engagement can be seen from some data that contain modulation as follows.

13. "Saya menyatakan Presiden harus mengubah imbauannya menjadi larangan untuk mudik”. (+ Engagement)

'I stated that the President must change his appeal to prohibit going home'. (EG, Detik)

14. "Presiden tidak boleh mencla-mencle. Jadi harus tetap pada himbauan saja," katanya. (+ Engagement)

"The president must not be hesitant. So he must stick to the appeal," he said. (EG, Detik)

As shown in data 13 and 14, harus 'must' serves as a positive engagement. As shown in data 13, the expert uses harus 'must' when commenting on the president's attitude. The expert intends to give a suggestion based on the president's behavior that is not following the expectations to act decisively to prohibit homecoming. As shown in data 14, harus 'must' is used. In this case, the expert gives an assessment that he did not object to the change in the meaning of homecoming, but he urges the president to have a clear paradigm or foundation for the change.

The counter expectancy is also found in some data to show engagement, for example,

15. “..."Tapi mereka memang pergi ke udik (hulu sungai, pedalaman) ..."

'....But they do go to udik (upstream, inland)....' (EG, Detik) 
Table 1. The result of attitude, gradation, and engagement analysis

\begin{tabular}{|c|c|c|c|c|c|c|c|c|c|c|}
\hline \multirow{3}{*}{ Source } & \multicolumn{6}{|c|}{ Attitude } & \multicolumn{2}{|c|}{ Gradation } & \multicolumn{2}{|c|}{ Engagement } \\
\hline & \multicolumn{2}{|c|}{ Affect } & \multicolumn{2}{|c|}{ Judgment } & \multicolumn{2}{|c|}{ Appreciation } & \multirow{2}{*}{+} & \multirow{2}{*}{ - } & \multirow{2}{*}{+} & \multirow{2}{*}{ - } \\
\hline & + & - & + & - & + & - & & & & \\
\hline \multicolumn{11}{|l|}{ Detik.news } \\
\hline Devie Rahmahwati (DR) & 2 & & 2 & & 2 & & 2 & & 1 & \\
\hline Effendi Gazali (EG) & 3 & 2 & 1 & 3 & 2 & & 1 & & 4 & \\
\hline Reporter & & & 5 & & 1 & & 1 & & 1 & \\
\hline \multicolumn{11}{|l|}{ Republika.co.id } \\
\hline Mahsun (M) & 1 & & 2 & & 1 & & 1 & & 2 & \\
\hline Reporter & & & 2 & & & & & & & \\
\hline
\end{tabular}

16. Apalagi beliau memiliki pengaruh yang sangat besar sebagai orangnomor satu di Republik ini. Bukankah makna kata atau tuturan ditentukan siapa yang mengucapkan kata itu.

Moreover, he has enormous influence as the number one person in the Republic. Isn't the meaning of a word or utterance determined by who pronounces the word? (M, Republika)

As shown in data 15, the expert uses sedangkan 'whereas' as cohesion of contradiction. The cohesion is used to emphasize the difference between homecoming and returning home. In data 16 the expert uses additional cohesion apalagi 'moreover' to emphasize that the president can change the meaning of homecoming as the president has a big influence. Furthermore, the expert uses rhetoric question bukankah 'isn't' to strengthen his argument that the meaning of homecoming can change because it depends on who is speaking in this case what he means is the president.

Unlike other studies carried out by Pusparini (2017), Gunawan et al. (2019), Burhanudin (2020), and Daniarsa and Mulatsih (2020) that make use of appraisal theory for political issues, this research focuses on how the language becomes a tool of legitimation of government policy, in this case, the redefinition of homecoming by the experts. Pusparini (2017) discusses the report of the duo Bali bombing on The Sydney Morning Herald, The Guardian Australia, The Jakarta Globe, and The Jakarta Post websites; Gunawan et al. (2019) discusses 212 movement reunion in Tirto online media; Burhanudin (2020) discusses the appointment of Ahok as the chief commissioner of Pertamina in Instagram; Daniarsa and Mulatsih (2020) discusses editorial headline on Papua case reported in Tempo and Kompas. Whereas, this research discusses how the President's statement on the redefinition of homecoming becomes legitimate by the support of experts in their statement reported in Detik and Republika media online. However, the research is in line with previous researches that have used appraisal theory. The research like previous research has used appraisal theory as a tool of analysis to unravel attitude inscribed in language unit, namely word, phrase, and clause as seen in the following table.
Based on Table 1, it is known that the two experts and reporters on Detiknews.com news have a positive attitude, gradation, and engagement towards redefining the word homecoming. Even though, EG gave negative judgment regarding the president's hesitant attitude when prohibiting homecoming and people around the president who influenced the president's policies regarding the handling of Covid-19. The two experts agreed that the redefinition of the word homecoming which is distinguished from going home is reasonable and acceptable to prevent the Covid-19 transmission during homecoming. Meanwhile, based on the table, it was found out the expert and reporter of Republika.com has a positive attitude, gradation, and engagement towards redefining the word homecoming. However, M's point of view emphasizes the linguistic aspect rather than the experts on Detik.com whose view from a historical point of view and public communication. This linguistic expert highlights the nature of language and it is associated with the sociolinguistic aspect that language cannot be separated from the context of who is speaking. Therefore, the president's effort to redefine the word homecoming by differentiating it from returning home is acceptable or legitimate by the approval of the experts.

\section{CONCLUSION}

Based on the findings and analysis on the news entitled "Perbedaan Mudik dan Pulang Kampung Menurut Para Ahli" posted by Detik.com on the $23^{\text {rd }}$ of April, 2020 and the news entitled "Pakar Linguistik Jelaskan Soal Arti Mudik dan Pulang Kampung" posted by Republika.co.id on the 24th of April, 2020. It can be concluded that experts and reporters have positive response about redefining the word mudik 'homecoming'. Through appraisal tools (attitude, gradation, and engagement) the positive attitude or acceptance or approval of these experts can be expressed. Expert opinions are reflected in their choice of words, phrases, clauses, intensifiers, modulations, etc. The experts' and reporters' positive response is a form of support not merely for the redefinition of the word mudik 'homecoming', it is also meant to assist the government effort to prevent the spread of Covid-19 through the act of local transmission or mass movement 
in time of mudik 'homecoming'. The expert's and reporters' positive responses can function as part of legitimization toward government policy in providing homecoming.

\section{REFERENCES}

Burhanudin, A. K. (2020). Analisis attitude terhadap penunjukan Basuki Tjahaja Purnama sebagai komisaris utama Pertamina dalam kolom komentar Instagram harian Kompas. Sosiohumaniora: Jurnal Ilmiah Ilmu Sosial Dan Humaniora, 6(1), 26-37.

Daniarsa, H. L., \& Mulatsih, S. (2020). Appraisal Analysis of Tempo's and Kompas' Editorials on Papua Cases. E-Structural (English Studies on Translation, Culture, Literature, and Linguistics), 3(01), 16-30.

Ellyawati, H. C. (2016). Analisis Wacana Kritis Teks Berita Kasus Terbongkarnya Perlakuan Istimewa terhadap Terpidana Suap Arthalyta Suryani pada Media Online. Jurnal The Messenger, 3(2), 19-35. http://dx.doi.org/10.26623/themessenger.v3i2.267

Firmansyah, T. (2020, April 24). Pakar Linguistik Jelaskan Soal Arti Mudik dan Pulang Kampung. Republika. https://republika.co.id/berita/q9ags4377/pakarlinguistik-jelaskan-soal-arti-mudik-dan-pulangkampung

Gunawan F., Thahara Y. And Risdianto F. (2019). Trick of Political Identity: Analyzing Appraisal System on 212 Movement Reunion in Online Media. Journal-Register, $12 \quad$ (1). 62-80. http://dx.doi.org/10.18326/rgt.v12i1.62-80

Martin, J. R., \& White, P. R. R. (2005). The Language of Evaluation. Appraisal in English. New York: Palgrave Macmillan.

Martin, J., and Rose, D. (2003). Working with discourse: Meaning beyond the clause. London: Continuum.
Munfarida, E. (2014). Analisis wacana kritis dalam perspektif Norman Fairclough. Komunika: Jurnal Dakwah dan Komunikasi, 8(1), 1-19.

Nur, A. M., \& Hadi, A. S. (2017). Realisasi Appraisal Dalam Aspek Attitude Pada Media Online Instagram.. Jurnal Sasindo UNPAM, 3(2), 15-24. http://dx.doi.org/10.32493/sasindo.v3i2.15-24

Pusparini, A., Djatmika, D., \& Santosa, R. (2017). Analisis Sistem Appraisal Berita Proses Eksekusi Duo Bali Nine (Pendekatan Linguistik Sistemik Fungsional). Paramasastra, 4(2). http://journal.unesa.ac.id/index.php/paramasastra.

Prabowo, D. (2020, April 9). Ketika Pemerintah Hanya Imbau Mudik dan Suruh ASN Ajak Masyarakat Tak Mudik. Kompas. Retrieved from https://nasional.kompas.com.

Sugiyono. (2006). Metode Penelitian Kuantitatif, Kualitatif dan $R$ \&. D. Bandung: Alfabet.

Tim Penyusun Kamus Besar Bahasa Indonesia, Badan Pengembangan Bahasa dan Perbukuan, Kementerian Pendidikan dan Kebudayaan Republik Indonesia. (2020). Kamus Besar Bahasa Indonesia Kelima (V) 0.4.0 Beta (40). https://github.com/yukuku/kbbi4

Winarni S. (2012). Analisis Appraisal System Kumpulan Wacana "Sungguh-Sungguh Terjadi" pada Surat Kabar Kedaulatan Rakyat. Unpublished Undergraduate Thesis. Universitas Negeri Yogyakarta

Young, L., \& Harrison, C. (Eds.). (2004). Systemic functional linguistics and critical discourse analysis: Studies in social change. A\&C Black.

Yunita, N. W. (2020, April 23). Perbedaan Mudik dan Pulang Kampung Menurut Para Ahli. detikNews. https://news.detik.com/berita/d4988213/perbedaan-mudik-dan-pulang-kampungmenurut-para-ahli 